\title{
SEX OFFENSES: A SOCIOLOGICAL CRITIQUE
}

\author{
StaNtoN WHEELER*
}

\section{INTRODUCTION}

Issues raised by sex offender legislation cut across a number of problems that are of interest to law, psychiatry, and the social sciences. Three problems are selected for brief review in this paper. The first concerns the basis for deciding what types of sex relationships should be subject to legal restraint. Second, the paper will review objective evidence regarding social attitudes toward various forms of sex conduct between consenting partners. Problems posed by more serious sex offenders will be examined in the closing section, with special attention directed to sex psychopath statutes and to possible sociogenic factors in the development of sex offenders. For rèisons of space, the special problems posed by prostitution are not considered. Since otther contributions to this symposium deal with experience in other societies and with the special problems of juveniles, the concern in this article is limited primarily to social norms and laws revelant to adult sexual relationships in the United States.

\section{I}

\section{Problems in the Definition of Sex Offenses ${ }^{1}$}

\section{A. Sex Relationships Subject to Legal Restraint}

Most of our sex laws are designed to govern one or more of four aspects of sexual relationships. Strongest legal sanctions are directed to control of the degree of consent in the relationship, with many states allowing the death penalty for forcible rape. Other bodies of sex law place limits on the nature of the object. Currently, most states restrict legitimate objects to humans, of the opposite sex, of roughly the same age, and of a certain social distance in kinship terms. Thus, sodomy or bestiality statutes prohibit relations with animals, parts of the sodomy statutes prohibit relations with members of the same sex, statutory rape and indecent liberties or child-molestation statutes restrict the legitimate age range of the partner, and incest statutes prohibit relationships with relatives other than the spouse. In addition, many jurisdictions, through fornication and adultery laws, limit legitimate objects to marriage partners. Legal restrictions

* A.B. I952, Pomona College; M.A. 1956, Ph.D. 1958, University of Washington. Instructor, Department of Social Relations, Harvard University. Sociologist, Washington State Department of Corrections, 1954-55. Contributor to sociological and correctional publications.

${ }^{x}$ Statutes defining sex offenses have been reviewed in a number of publications and will not be discussed in detail here. Major sources on which this discussion is based include Robent V. SHERwiN, SEx and the Statutory Law (i949); Morris Ploscowe, Sex and the Law (1951); Bensing, a Comparative Study of American Sex Statutes, 42 J. Crim. L., \& P.S. 57 (195I). Sce also Ploscowe, Sex Offenses: The American Legal Context, supra pp. 217-24. 
are also placed on the nature of the sexual act. Full legitimacy is restricted largely to acts of heterosexual intercourse. Even if the object is a legitimate sexual object, the act may be subject to severe legal sanction. Thus oral-genital contacts, digital manipulation, and common-law sodomy are legally deviant acts, although they may occur by consent between a married pair. Finally, the law attempts to control the setting in which the act occurs. Relationships that are otherwise subject to no restraints may become so when they occur publicly or when carried on in such a manner that the public may easily be aware of the relationship. States that do not punish single or even repetitive acts of fornication or adultery may do so if there is evidence of "notorious" show of public indecency. Public solicitation statutes as well as indecent exposure laws are likewise oriented to control of the setting, rather than the act itself.

\section{B. Aims of the Criminal Law}

If there were an explicit and articulate rationale underlying the criminal law's attempts to control sex conduct, one might expect that the legal sanctions attached to the various relationships would show an orderly pattern. That nothing could be further from the case is a frequently-noted and often-condemned fact. ${ }^{2}$ The wide disparity in definitions of sex offenses and in severity of sanctions reflects, in part, the differential judgment of the seriousness of all sex offenses. In addition, it reflects differing judgments of the relative seriousness of differing types of sex relationships. Some understanding of the sources of disparity emerges from consideration of the various and conflicting aims of the criminal law as it applies to sex offenses.

A traditional emphasis views the criminal law as reflecting the moral condemnation of the community. Emile Durkheim's discussion of the universal elements in crime stressed the feature of moral condemnation. Crimes "shock sentiments which, for a given social system, are found in all healthy consciences."3 Crimes consist "in acts universally disapproved of by members of each society." The image of a homogeneous community reacting through the collective conscience was forcefully presented as the characteristic reaction to crime. A vigorous statement of a similar position has recently been made from a legalistic perspective. Henry $M$. Hart has defined crime as "conduct which, if duly shown to have taken place, will incur the formal and solemn pronouncement of the moral condemnation of the community." He has voiced the fear that this element may be lost in sentencing procedure, even if retained in the definition of crime, if corrective and rehabilitative emphases predominate.

The element of moral condemnation in sex laws is vividly portrayed in statutes

${ }^{3}$ Morris Ploscowe, Sex and the Law 136-55 (r95r).

${ }^{3}$ Emille Durkheim, ON the Division of Labor in Society 73 (George Simpson transl. r933).

Ibid.

"Hart, The Aims of the Criminal Law, 23 Law \& Contenp. Prob. 40r, 405 (1958). Hart also has emphasized the obligations imposed by community life, although these obligations are only indirectly caught up in his formal definition. See $i d$. at 413,426 . 
defining "crimes against nature." The very use of such a vague and ill-defined concept is related to the revolting nature of the behavior. Ploscowe has noted a judge's ruling in such a case: ${ }^{6}$

It was never the practice to describe the particular manner of the details of the commission of the crime, but the offense was treated in the indictment as the abominable crime not fit to be named among Christians. The existence of such an offense is a disgrace to human nature. The legislature has not seen fit to define it further than by the general term, and the records of the courts need not be defiled with the details of the different acts which may go to constitute it. A statement of the offense in the language of the statute is all that is required.

A different basis for the definition and grading of crimes is reflected in the conception that the criminal law should punish only those acts that are socially dangerous, independent of their moral character. The American Law Institute's Model Penal Code ${ }^{7}$ and the Wolfenden Report ${ }^{8}$ in England have been strongly influenced by this conception in the drafting of recommendations regarding sex offender laws. In recommending the restriction of the crime of fornication to open and notorious acts and those involving adoptive parents and children, the draftsmen of the Model Penal Code justify their position as follows:"

The code does not attempt to use the power of the state to enforce purely moral or religious standards. We deem it inappropriate for the government to attempt to control behavior that has no substantial significance except as to the morality of the action.

Throughout the discussion of code provisions, emphasis is clearly placed on control of behavior that appears to show some immediate social harm, either through the use of violence, through the exploitation of children, or through the nuisance value of public indecency.

The Wolfenden Report reflects a similar concern. It has been noted that "the yardstick applied throughout was utilitarian. If it could be proved that the behavior of an individual was socially injurious, he or she must be restrained."10 Sex offenses are to be distinguished from sins and controlled in accordance with their objective social danger, rather than the degree of moral arousal they bring about.

A third criterion for the establishment of sex legislation has emerged during the past two decades. It is part of the growing influence of rehabilitative concerns on the administration of criminal law. This criterion reflects neither the moral condemnation nor the social danger of the offense; rather, the stress is on the degree of psychopathology characterizing the offender. The influence of this conception has been extended from sentencing and treatment considerations to the definition of antisocial acts. Some of the sex psychopath statutes have allowed commitment up to life for persons showing such characteristics as "emotional instability, impulsive-

${ }^{6}$ Morris Ploscowe, Sex AND the LAw 197 (195I).

${ }^{7}$ Model Penal Code art. 207 (Tent. Draft. No. 4, x955; Tent. Draft No. 9, 1959).

${ }^{8}$ Committee on Homosexual Offenses and Prostitution, Report, CMND No. 247 (1957).

- Model Penal Code $\$ 207.1$, comment at 207 (Tent. Draft No. 4, 1955).

${ }^{10}$ Eustace Chesser, Live and Let Live ix 1 (1958). 
ness, lack of good judgment, failure to see consequences of act, irresponsibility in sex matters . ..."11 Clearly, the emphasis is on personal qualities of the offender, rather than on the seriousness of any particular act.

Finally, there is increasing recognition of the important practical criterion of enforceability. The lack of visibility of most forms of sexual relations between consenting partners means that detection and arrest are nearly impossible for the vast number of cases. Such lack of enforceability may become another basis for judgment of selection of legal sanctions. Practical problems of enforcement are reflected in Model Penal Code recommendations concerning adultery and in discussion of the possible withdrawal of penal sanctions for deviate sexual intercourse between consenting adults. $^{12}$

Current sex statutes reflect these varying aims of the criminal law. They do not fit a single dimension of social evaluation, but instead catch up in differing degrees the aims of expressing a) the community's sense of moral condemnation or revulsion; b) the degree of social harm resultant from the act; c) the degree of psychopathology characterizing the offender; or d) by omission, the practical problem of enforcement. Thus, it is no surprise that our sex laws are inconsistent and contradictory. A consistent criminal code for sex offenders is unlikely to emerge until there is agreement on the fundamental aims of the criminal law in this area.

\section{Trends and Problems}

The Model Penal Code and the Wolfenden Report give evidence of a movement toward a consistent framework for the criminal law regarding sex offenses. As noted, this framework places the social-danger criterion at the apex of the aims of the criminal law, assigns a lesser but important role to the aim of enforceability, and restricts the expression of the moral condemnation of the community to such cases as are also viewed as socially dangerous. This shift away from a moral emphasis presents some problems that deserve brief mention.

A chief difficulty in implementing a criterion of moral condemnation lies in the diversity of moral sentiment in modern communities. Durkheim's conception of a universal response to deviance was perhaps overdrawn, even for primitive communities. It seems particularly unrealistic in application to contemporary western societies. The very changes that were indexed by the growth of restitutive law have brought about also a change in the collective response to criminals. Increasing social differentiation makes it difficult to find acts that are universally condemned. To speak of moral condemnation of the community is to use the term community in a very loose sense. It may apply to certain acts of violence and to crimes against children. Beyond these areas are many actions where no single community opinion can be said to exist. Responses to gambling laws, to white-collar violations, or to

\footnotetext{
${ }^{11}$ From a 1949 Indiana statute, as described in California Dep't of Mental Hygiene, Final Report on California Sexual Deviation Research 45 (1954).

${ }^{12}$ Model Penal Code 277-78 (Tent. Draft. No. 4, I955).
} 
sex offenses between consenting partners depend heavily on the cultural background of the offender or of the person making the judgment. These influences play upon processes of adjudication and help to produce the great disparity in sentencing policies in different jurisdictions. Thus, the conception of a homogeneous community response, as implied by the moral condemnation argument, fails to square with contemporary life. ${ }^{13}$

In the face of these problems, the aim of limiting criminal sanctions to socially dangerous acts has great appeal. It purports to avoid the problem of differing moral judgments by establishing an objective standard of social danger; if acts surpass a certain minimal level, they are to be defined as crimes and graded as to severity according to the degree of danger involved.

The difficulties in working out such a formulation are evident in parliamentary response to the Wolfenden Report recommendations on homosexuality. There appeared to be general acceptance of the argument that conduct not injurious to society falls outside the legitimate concerns of the criminal law. But members of the House of Commons were uncertain that homosexuality between consenting adults was not injurious. There was fear that others might easily be corrupted if the act is not criminal-that persons will be willing to experiment with homosexual relations. ${ }^{14}$ There was also the fear that removing the legal sanctions might imply condonation of homosexuality. ${ }^{15}$

Thus, even though there is no clear and present danger of bodily harm or corruption of morals in acts between consenting adults, there is always the possibility of long-term harmful consequences. Arguments to this effect can always be made and are hard to refute on empirical grounds, especially where the effects, if any, are likely to be subtle and only shown over a long time span. Although the history of legal control of sex conduct is largely one of failure, ${ }^{16}$ this fact is a commentary on the problem of enforceability of the law; it does not, of itself, establish anything about the degree of social danger of the conduct. It is always possible to argue, as members of Parliament did, that conditions could be worse were the laws not on the books. ${ }^{17}$

${ }^{13}$ Cf. Fuller, Morals and the Criminal Law, 32 J. CRIM. L. \& C. 624 (1942). Evidence on variation in sentences comes from a variety of sources and is summarized in Glueck, Predictive Devices and the Individualization of justice, 23 LAw \& Contemp. Prob. 463 (I958).

14 Murray, Commons Debate on the Wolfenden Report, 122 Just. P. 816 (I958).

${ }^{15}$ Wolfenden Report in Parliament, 1959 Crns. L. REv. (Eng.) 38. The recommendations of the Wolfenden Committee are discussed in greater detail elsewhere in this symposium. Hall Williams, Sex Offenses: The British Experience, infra pp. 334-60.

${ }^{10}$ All authorities are in agreement on the failures of legal controls, and the evidence is well known. Most states have almost no prosecutions under fornication, seduction, or adultery statutes. To quote Ploscowe, "Nowhere are the disparities between law in action and law on the books so great as in the control of sex crimes." Morris Ploscowe, SEx AND THE LAw 155 (1951). Nor is this a recent phenomenon. Geoffrey May cites data for the town of Groton, Mass., showing extremely high rates of fornication during the height of puritanism in the colonies. Geoffrey May, Social Control or Sex Expression 254 (1930). When the Model Penal Code discussions review problems of enforceability, fairly good evidence for the claims is presented. When the discussions concern possible secular harms, claims are based largely on argument and opinion. See, e.g., the discussion of adultery. Model Penal Conts $\S 207.1$, comment at 204-xo (Tent. Draft No. 4, I955).

${ }^{17}$ A similar problem is evident in discussions about the effectiveness of correctional techniques. It is fashionable to think of the "new penology" as based on rational, scientific investigation; yet, there is little 
This suggests something of the circular relationship likely to be maintained between social danger and moral condemnation as factors influencing public discussions and legislative decisions. The shift to an emphasis on the secular harms of various acts withdraws attention from their moral character. But in the absence of any clear-cut criterion of social danger, moral considerations will enter into and influence the perception of what is or is not socially dangerous. Until the consequences for society of various types of sex relationships are better known, changes in sex legislation will have to be based largely on changes in attitude and ideology, rather than on compelling evidence.

\section{II}

\section{Social Norms and Sexual Conduct}

The Kinsey volumes provided the first detailed account of sexual practices in the United States. ${ }^{18}$ Public interest in the reports revealed the high degree of curiosity and anxiety aroused by the topic. But precisely because the subject of sex calls forth anxieties and fears, there has been a tendency for behavioral scientists to shy away from the systematic study of sexual attitudes and norms. No study of social norms regarding sexual conduct comes close to matching in quantitative detail the knowledge about sex acts contained in the Kinsey, volumes. The result is that we have only meager evidence concerning the social evaluation of sexual conduct, as distinguished from the conduct itself.

Such evidence as is available comes from a variety of sources. The Roper Fortune Surveys have included a few items on sex attitudes in their national sample surveys over the past twenty-five years. Attitude questionnaires have been administered to select samples of individuals, primarily college students. Some case studies of particular communities or subcultures yield a modicum of data on normative patterns. Finally, inferences can be drawn from certain gross features of societal concern for sex relationships.

The data bear upon three questions frequently raised in discussions of sex mores: Is there evidence of a trend toward increasing permissiveness? Are there widespread subcultural differences in social norms regarding sexual conduct? Do the norms bear a close relationship to sexual behavior?

\section{A. Trends in Values}

Changes in American values during the twentieth century point to a widespread increase in sexual permissiveness, at least as gauged by the increasing freedom and

cvidence that current techniques are any more effective than those used in the past. Increasingly, evaluative research is carried out to test the effectiveness of various programs. Even the best of the studies are subject to methodological weaknesses that make for ambiguity in results, so that interpretations may be made consistent with the ideology of the interpreter. See Cressey, The Nature and Effectiveness of Correctional Techniques, 23 LAW \& Contexp. Prob. 754 (r958).

${ }^{18}$ Alfred C. Kinsey, Wardell B. Pomeroy \& Clyde E. Martin, Sexual Behavior in the Human Male (I948) [hercinafter cited as Kinsey Male Report]; Alfred C. Kinsey, Wardeil B. Pomeroy, Clyde E. Martin \& Paul H. Gebhard, Sexual Behavior in the Human Female (i953) [hereinafter cited as Kinsey FeMile Report]. 
lack of restraint in discussing sexual matters. Instead of the "Society for Sanitary and Moral Prophylaxis," the mid-twentieth century has a "Society for the Scientific Study of Sex." The pervasive influence of Freudian conceptions and the interest generated by the studies of Havelock Ellis are indicators of the same trend. The change has received support in modifications of obscene literature statutes, as brought forth most vividly in the recent case involving Lady Chatterly's Lover.10 Although commentaries speaking darkly of a "sex revolution" pervading every aspect of social life seem highly overdrawn, ${ }^{20}$ there is abundant evidence of increasing public attention and discussion of sexual codes. ${ }^{21}$

There is a vast difference, however, between the change in mores allowing greater freedom of discussion and a change reflecting either greater approval or a higher incidence of particular types of sex relationships. It is more difficult to find solid evidence for the latter type of change. Kinsey's data suggested, for instance, that the major change in rates of premarital intercourse for females occurred with those born between I900 and I9ro. Women born during the period from 1910 to 1930 had roughly the same pattern as those born during the first decade of the twentieth century. ${ }^{22}$ And while younger-generation males had slightly higher rates of premarital intercourse with companions, the difference was largely offset by relatively more frequent contacts with prostitutes among the older-generation males. ${ }^{23}$ The incidence of homosexuality and adultery also remained relatively constant, although suggesting slight intergenerational changes for different segments of the population. ${ }^{24}$

Caution must be used in interpreting these findings, for there are well-known methodological problems in the Kinsey volumes, the most important being the use of nonprobability sampling, volunteer subjects, problems of recall among the older respondents, and the possible differences between reported and actual behavior. ${ }^{25}$ Within these limitations, the findings give no indication of significant changes in the gross features of sexual conduct since the I920's.

Studies of the social evaluation of sexual conduct reveal a similar pattern. Impressionistic accounts of changes in the mores suggest that intercourse outside of marriage is increasingly viewed as an acceptable form of conduct. Unfortunately, there

${ }^{10}$ Kingsley Int'l Picture Corp. v. Regents, 360 U.S. 684 (1959).

${ }^{20}$ Pitirim A. Sorokin, The American Sex Revolution (1956).

$21 \mathrm{~A}$ major review of changes in American values shows increasing discussion of sex and a rising interest in extramarital relationships revealed in content analyses of best sellers. Sec Kluckhohn, Have There Been Discernible Shifts in American Values During the Past Generation?, in Elting E. Moruson, The AMerican Strze I45 (1958). For changes of a similar sort during earlier decades, sec Newcomb, Recent Changes in Attitudes Toward Sex and Marriage, 2 AM. Soc. REv. 659 (1937). For interesting essays on the subject, see Abram Kardiner, Sex and Morality (I954).

25 KINSEY FEMALE RePORT 242-46.

${ }^{23}$ Kinsey Male Report $4 \mathrm{I} \mathrm{I}-\mathrm{I} 3$.

24 Id. at 4 13-I7.

${ }^{25}$ An excellent review of the methodological problems in the Kinsey report on males is provided by Wirliam G. Cochiran, Frederick Mosteller \& John Tukex, Statistical Problems of the Kinsey REPORT (I954). These authors discuss the problem of establishing the stability of sexual patterns and caution against drawing more than tentative conclusions. Id. at I4I. 
is no solid empirical evidence that can be used to evaluate this claim over a long time span, for objective methods of attitude and opinion assessment were not in use prior to the r930's. The best available evidence for a more recent period consists in responses of national samples to an item asked in 1937 and again in 1959 by the Roper polling agency. If major changes in attitudes have occurred during the past twenty years, this fact should be revealed in the Roper data.

The question asked on both polls was: "Do you think it is all right for either or both parties to a marriage to have had previous sexual experience?"26 Responses are indicated in table one. The results show a surprisingly stable pattern over the past two decades. When it is remembered that the period spanned included publication and widespread discussion of the two Kinsey volumes, it is apparent that the fears voiced in some quarters-that knowledge of the Kinsey results may have widespread effect on sexual standards-have not materialized.

TABLE I

"Do You Think It Is All Right for Either or Both Parties to a Marriage to Have Had Previous Sexual Intercourse?"

\begin{tabular}{|c|c|c|}
\hline & 1937 & 1959 \\
\hline \multirow[t]{2}{*}{ 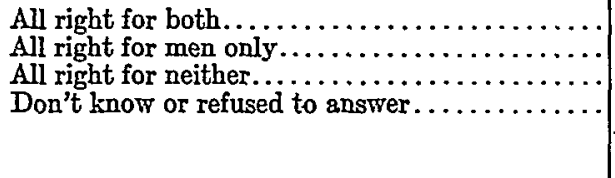 } & $\begin{array}{r}22 \% \\
8 \% \\
56 \% \\
14 \%\end{array}$ & $\begin{array}{r}22 \% \\
8 \% \\
54 \% \\
16 \%\end{array}$ \\
\hline & $100 \%$ & $100 \%$ \\
\hline
\end{tabular}

It is, indeed, risky to base a conclusion on such limited evidence. Other interpretations than that of stability could be given. There may have been widespread shifts in opposite directions for different segments of the population, such that they cancel out in the summary findings. There may have been important changes of such a subtle nature that they are not reflected by a single item on an opinion poll. The results may be reliable, but may have caught the population at particular points in a cycle of sexual attitudes, thus giving a false appearance of stability. All of these interpretations are possible and cannot be refuted without further evidence. The simplest interpretation, however, is that there has been little over-all change in attitudes toward this form of sexual conduct over the period spanned by the studies. ${ }^{27}$

${ }^{20}$ The I937 data are from The Fortune Quarterly Survey: VIII, Fortune, April r937, pp. IIx, r88-90. The 1959 results were supplied to the writer by Phillip K. Hastings, Director, The Roper Public Opinion Research Center, Williams College, Williamstown, Mass. Results from these surveys demonstrate the dangers in inferring trends from comparison of older and younger generations at a single point in time. In both surveys, the older generation were somewhat less approving. The trend data suggest that this is largely a function of age, rather than a changing climate of opinion.

${ }^{27}$ Studies of moral values among samples of college students provide some evidence of change over recent decades. One study compared the responses of students in 1939 and in 1956 on an instrument designed to assess the perceived importance of certain characteristics in the ideal marriage mate. It found a decline in the importance attributed to chastity consistent with an assumed change from traditional to romantic and companionship factors as bases for mate selection. McGinnis, Campus Values in Mate Selection: A Repcat Study, 36 Social Forces 368 (1958). A similar study, however, notes an increase 


\section{B. Socioeconomic Status and Sex Attitudes}

One argument frequently raised in support of a change in legal controls is that communities are no longer homogeneous with respect to sexual standards-that the wide range of standards held in different segments of the population precludes application of universalistic legal standards. Kinsey's data are usually cited in support of this contention. ${ }^{28}$ The most important of Kinsey's findings for present purposes are the variations in rates of premarital intercourse and in techniques of sexual arousal. Kinsey found that rates of premarital intercourse for males were highest at low educational levels and were considerably lower among the college-educated segment of his population. ${ }^{29}$ At the same time, he found that lower-level couples were likely to restrict their sexual contacts to the most direct form of sexual union, while upper-level couples employed a wide variety of coital techniques, mouth and breast stimulation, and manual and oral forms of genital stimulation. For example, oral stimulation of female genitalia was found in sixty per cent of the college-educated segment, but in only twenty and eleven per cent of the high-school and grade-school histories, respectively. ${ }^{30}$ The direction of these relationships suggests that sex statutes. limiting premarital intercourse are most frequently violated by lower-class members, while statutes defining various forms of heterosexual perversions are more likely to be violated by middle- and upper-level persons.

There is little systematic evidence to determine whether the normative patterns are consistent with the differential incidence rates for perversions. Kinsey suggests that his lower-level respondents viewed with disgust some of the petting and coital practices of middle- and upper-level persons, although systematic evidence is lacking. The pattern, if verified, is an interesting reversal of the usual view that legal standards of sexual conduct reflect a middle-class morality.

More evidence is available concerning the social evaluation of premarital intercourse at differing socioeconomic levels. Between 1939 and 1943, the Roper agency asked questions about sexual attitudes in three of their sample surveys. ${ }^{31}$ Typical results are reported in tables two and three. The question for table two was: "Do you consider it all right, unfortunate or wicked when young men (women) have sexual relations before marriage?" For table three, the question was: "Should men (women) require virginity in a girl (man) for marriage?" Variation in response

in the severity of moral judgment regarding forms of promiscuity. See Rettig \& Pasamanick, Changes in Moral Values Among College Students: A Factorial Study, 24 AM. Soc. Rev. 856 (1959). Whilc the increase in severity of judgment on three items dealing with sex was less than that for many other items, the values are still quite strong. For instance, "having illicit sex relations after marriage" was judged a more severe moral transgression than "nations at war using poison gas on the homes and cities of its enemy behind the lines"; or "a legislator, for a financial consideration, using his influence to secure the passage of a law known to be contrary to public interest."

${ }^{28}$ Model Penal Code $\$ 207.1$, comment at 206-07 (Tent. Draft No. 4, 1955).

20 Kinsey Male Report 347.

30 Id. at 576-77.

${ }^{31}$ I wish to acknowledge the aid of the Roper Public Opinion Research Center in making the data available for analysis. Unfortunately, evidence on class distribution of responses for the 1959 item was not yet available for study. 
by socioeconomic status is similar in both tables, although the strength of the relationship varies with the wording of the question. ${ }^{32}$ The relationship is also found when occupation is used as the relevant variable. Among males, the proportion who felt such activity was wicked increased from twenty-six per cent among white-collar and professional workers to thirty, thirty-five, and thirty-six per cent among bluecollar, unemployed, and farmers, respectively.

TABLE II

"Do You Consider It All Right, Unfortunate or Wicked When Young Men (Women) Have Sexual Relations Before Marriage?” (Women Only; $N=5220$ )

\begin{tabular}{|c|c|c|}
\hline Socioeconomic Status & Wicked for Men & Wicked for Women \\
\hline 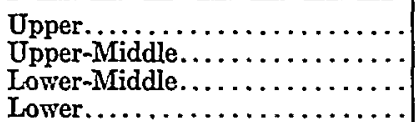 & $\begin{array}{l}28 \% \\
34 \% \\
40 \% \\
53 \%\end{array}$ & $\begin{array}{l}36 \% \\
43 \% \\
50 \% \\
62 \%\end{array}$ \\
\hline
\end{tabular}

TABLE III

"Should Men (Women) Require Virginity in a Girl (Man) for Marriage?" (WOMEN ONLX; $N=2570$ )

\begin{tabular}{|c|c|c|}
\hline Socioeconomic Status & $\begin{array}{c}\text { Men Should } \\
\text { Require in Women }\end{array}$ & $\begin{array}{l}\text { Women Should } \\
\text { Require in Men }\end{array}$ \\
\hline 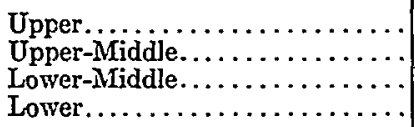 & $\begin{array}{l}64 \% \\
66 \% \\
71 \% \\
72 \%\end{array}$ & $\begin{array}{l}42 \% \\
47 \% \\
53 \% \\
52 \%\end{array}$ \\
\hline
\end{tabular}

What is surprising about the Roper results is not the degree of variation by social class, but its direction. Those in lower social strata are more likely to express disapproval of intercourse outside of marriage than are those in middle and upper positions. This is precisely the reverse of the direction for the behavioral record as found by Kinsey and others. The discrepancy could be due to such factors as a greater tendency among lower-class respondents to give what they perceive as socially desirable responses to middle-class interviewers, or the correlation of social class. with religion or other variables. Certainly, the data are not strong enough to accept the finding as confirmed; yet, it does call into question the inference, frequently drawn by Kinsey's interpreters, that the social-class differences in rates are strongly supported by class differences in sex attitudes and values. ${ }^{\mathbf{3 3}}$

There are reasons to believe that the relationship between overt sex acts and cultural values is much more complex than is usually presumed. Thus, a growing body

${ }^{33}$ The socioeconomic labels are interpreted from an index used by the Roper agency and may not match the distinctions made in other studies. These distributions probably fail to catch the extreme top and bottom of the socioeconomic scale, where different patterns might emerge. Data are for white respondents only.

${ }^{30}$ Kinsey's own interpretations frequently were based on this assumption. Other examples are included in Jerome Himelhoch \& Sylvia Fava, Sexual Behavior in American Society 175-205 (1955). 
of research has documented the higher degree of intolerance for deviant behavior among those of low education and socioeconomic position. ${ }^{34}$ The response to sex may be part of the broader tendency to see the world in a good-evil dichotomy. The tendency is reinforced by the dogmatism of fundamentalist religious groups likely to flourish and have greatest appeal to those in lower social strata. ${ }^{35}$ Class differentials in tolerance for sexual expression are also indicated in recent studies of child-rearing patterns. Working-class mothers are found to be far less permissive and to use more punitive measures for preventing sexual exploration. ${ }^{36}$ These findings would lead one to expect greater rather than less disapproval at lower socioeconomic levels.

At the same time, the objective life situation of lower socioeconomic groups may predispose them to greater pressure for engaging in the activity. Thus, studies of lower-class urban areas point to the frequency of female-based households in which if the mother is to have any normal sexual outlet, it becomes, by definition, adultery. ${ }^{37}$ The greater amount of premarital intercourse among lower-class girls may reflect less a difference in stated values than the use of sex as a means of attracting males of higher status, in the absence of alternative qualities of attraction..$^{38} \mathrm{~A}$ related and important feature concerns differences in the use and effectiveness of social-control techniques. For example, the more punitive methods of child-rearing used in lower socioeconomic strata may be less effective in producing long-term internal controls, even though parental attitudes may be similar to those in other strata.

All of these features may operate to suppress the effect of cultural values on overt conduct. One of the reasons the relationships between socioeconomic status, sex attitudes, and sex behavior are not yet clearly understood is that they are probably quite complex, involving differential pressures for engaging in the behavior and different mechanisms of control. A particular pattern of conduct emerges from many social influences and is rarely a simple reflection of stated cultural values. These influences are frequently neglected in drawing conclusions from the Kinsey research. ${ }^{39}$

\footnotetext{
${ }^{34}$ Samuel A. Stouffer, Communism, Conformity, and Civil Liberties 89-108 (1955); Lipset, Democracy and Working Closs Authoritarionism, 24 AM. Soc. REv. 482 (1959).

${ }^{30}$ See Liston Pope, Millihands and Preachers (r942).

${ }^{36}$ Robert R. Sears, Eleanor E. Maccoby \& Harry Levin, Patterns of Child Rearing 428 (I957).

${ }^{37}$ See Miller, Implications of Urban Lower-Class Culture for Social Work, 23 Soc. Senv. REv. 225 (I959); see also Allison Davis \& John Dollard, Children of Bondage 272-90 (1940).

${ }^{38}$ See Kanin \& Howard, Postmarital Consequences of Premarital Sex Adjustments, 23 AM. Soc. Rev. 558 (1958); see also Ehrmann, Infutence of Comparative Social Class of Companion Upon Premarital Heterosextlal Behavior, I7 MARRIAGE \& FaMily Living 48 (x955).

${ }^{39}$ A related point of misinterpretation hinges on Kinsey's use of an accumulative-incidence curvc, which reflects single acts engaged in only during childhood, or perhaps on only one occasion as an adult. One can hardly assume that because an act has been committed at least once by the majority of the population, it is, therefore, regarded as culturally acceptable. Yet, this argument has apparently been used in court cases. See Himeshoch \& Fava, op. cit. supra note 33, at 244-50. On this basis, one would withdraw a large proportion of penal legislation, at least as it applies to males, including that governing tax evasion, malicious mischief, auto misdemeanors, disorderly conduct, and larceny. See Wallerstein \& Wyle, Our Law Abiding Law-Breakers, 25 Probation ro7 (I947).
} 
C. Other Structural Characteristics and Sex Attitudes

Considerable variation in sex attitudes is revealed when characteristics other than social class are studied. Even a single question on a public opinion poll reveals important differences in attitude by race. Where roughly fifteen per cent of the white females said that premarital intercourse for males was "all right," twenty-nine per cent of the Negro females gave that response. The differences in tolerance for women who engaged in the same behavior ranged from roughly five per cent for white respondents to seventeen per cent for Negroes. ${ }^{40}$ Evidence on sex behavior leaves no doubt that the attitudinal differences are carried out in action. A study of army recruits located seven virgins among 500 Negro draftees. ${ }^{41}$ Studies of illegitimate birth point to the extremely high rates for Negro girls in urban areas.

Kinsey's results revealed the influence of religious affiliation on sexual attitudes and behavior. Increasing rates of premarital intercourse are observed as one moves from Jewish to Catholic to Protestant groups. For each religious grouping, the proportion of women voicing regret for having premarital intercourse was greatest among the most active believers. ${ }^{42}$

Regional and rural-urban differences are revealed in recent opinion poll results: permissive attitudes are highest in the urban Northeast (twenty-eight per cent), followed by the Far West (twenty-six per cent), the South (twenty-three per cent), and the Mid-west (fifteen per cent). ${ }^{43}$ The same data also indicate that the double standard applies most clearly to Southern manhood. Thirteen per cent of the Southern respondents, compared to about five per cent in the other areas, say that premarital sex is "Okay for men only."

The above review of variation in social norms in differing sectors of society is probably a conservative statement of the actual variation, for it has been impossible to assess the combined effect of the several characteristics. At the same time, citation of percentages engaging in this or that conduct or holding particular attitudes tends to obscure the general lack of clarity of sex codes. With the exception of certain extremes found among particular ethnic or religious subcultures, it is probably fair to say that no single normative pattern is institutionalized in any large segment of the population, let alone the society as a whole. The wide variation in response to the Kinsey volumes gives abundant testimony to this fact. ${ }^{44}$

In part, the lack of clarity of sex codes is due to the specificity of sex attitudes. Whether premarital intercourse is viewed as acceptable or not depends on many features of the relationship between the couple. The sociologist William F. Whyte noted that Italian street-corner boys made a clear differentiation between "good girls," with whom intercourse was prohibited, and "lays" with whom it was highly

${ }^{10}$ In response to the question reported in table II supra.

"Hohman \& Schaffner, The Sex Lives of Unmarried Men, 52 AM. J. Soc. 501 (1947).

19 Kinsey FeMnle Report 319.

${ }^{13}$ From the 1959 Roper survey reported in table I supra.

"See Palmore, Published Reactions to the Kinsey Report, 3I Social Forces I65 (1952). 
desirable. $^{45}$ Studies of college students and middle-class sexual patterns suggest that intercourse is more acceptable to girls if part of a love relationship, while males are less likely to view it as acceptable under those conditions (although at any point, of course, premarital intercourse for males is considered more acceptable than for females.) ${ }^{46}$ Until recently, the social scientists' concern with sexual attitudes and conduct was limited largely to the gross features of such conduct as revealed by frequency counts and general opinion. The meaningful context of the behavior or attitude was seldom studied in detail. The growth of a body of knowledge about the meaning of the activity for participants should provide a more useful set of empirical findings on the social distribution of sex attitudes and behavior. ${ }^{47}$

A more pervasive influence is the lack of visibility of sex attitudes and behavior. To an important degree, no one knows what standards others are employing. Enough life remains in the puritan ethic to prevent persons from expressing their attitudes openly. This quite naturally produces a condition of pluralistic ignorance. Without this element, it would be hard to account for the amazing public interest in the Kinsey reports. And so long as the condition remains, it will be impossible to achieve any genuine normative consensus.

\section{Homosexuality}

Little can be said about attitudes toward other forms of sexual relations between consenting adults. While much has been written about the homosexual problem, there is almost no objective information on the degree of public tolerance for homosexuals or on conceptions of the desirability of penal sanctions as a means of control. Although mass responses are still shrouded in mystery and fear, the trend is surely toward a more enlightened, dispassionate perspective. ${ }^{48}$

Some inferences as to sources of changing perspectives can be drawn from other studies of tolerance toward deviance. As noted above, an increasing body of research

45 Whyte, A Slum Sex Code, 49 AMer. J. Soc. 24 (1943).

${ }^{40}$ Ehrmann, Premarital Sexual Behavior and Sex Codes of Conduct with Acquaintances, Friends and Lovers, 38 SOCIal FoRces 158 (1959).

${ }^{47}$ One of the major complaints in popular literature about the Kinsey research was the overly biological orientation and lack of attention to love and affection as basis for sex relationships. Some of Kinsey's results as well as those of other investigators suggest, however, that where the abstinence standard no longer exists, the emerging standard permits coitus when part of a stable, affectionate relationship. See Reiss, The Treatment of Pre-Marital Coitus in "Marriage and the Family" Texts, 4 Social ProvLEMS 334 (1957). An interesting recent study finds a high degree of cgo involvement in premarital sexual relationships, particularly among middle-class women, and suggests some of the conditions that encourage intimacies for females in the middle and upper sociocconomic strata. Sec Vincent, EgoInvolvement in Sexual Relations: Implications for Research on Illegitimacy, 65 AM. J. Soc. 287 (1959).

18 Contributing to and reflecting this trend is an increasing willingness on the part of some homosexuals to make their problems a matter for public concern. Sce, e.g., PETER WiLdebloup, AGainst THE LAW (x956). And note the signs of incipient pressure-group formation in the following quotation from the trade journal, One, published in Los Angeles: "No American Politician regards as humorous a millions votes. . . . Let's say the membership dues are ... fifty cents a month ... six dollars a year ... multiply that by a million and you have the gigantic fighting strength . . \$ \$6,000,000. . . . Nobody will care whose money it is . . that of screaming pansies, delicate decorators or professional wrestlers, Nobody will give a damn because this is the U.S.A. and money talks. . ." From the Sept. 1953 issue of One, as quoted in James M. Reinhardt, Sex Perversions and Sex Crimes 32 (1957). 
suggests that tolerance toward nonconforming behavior may be a relatively general trait that may cut across many specific forms of deviation. ${ }^{49}$ Tolerance is greatest among the younger generation and those with most education. The sociologist Samuel Stouffer's report on political nonconformity found tolerance also greater among community leaders. ${ }^{50}$

Whether these results hold for attitudes toward sexual nonconformity can only be determined by further study. The findings at least suggest the important sectors of the population that may be least resistive to changes of the type recommended by the Wolfenden Report in England. While such proposals are probably still in advance of public opinion, the forces making for greater tolerance are likely to remain and should be a sign of hope for supporters of more liberal legislation regarding homosexuals. ${ }^{\text {I1 }}$

\section{E. Need for more Adequate Information}

Review of objective data on social norms and sexual conduct reveals above all .else the paucity of useful information. Aside from an occasional item in an opinion poll, a handful of studies of college students, and one or two anthropological accounts, there is nothing that even makes for intelligent speculation as to the sources and types of community reaction to sexual deviations between consenting adults. Such evidence as is available suggests that while there has been no great change in standards of sexual conduct at least over the past twenty years, there is a general trend toward greater tolerance of various forms of sexual relationships. Some of the more recent proposals for change in legislation invoke distinctions between mental illness, crime, and sin that major segments of the public are probably not yet prepared to understand or accept. Perhaps the single most important factor making for public recognition of these distinctions is the increase in average level of education.

The outstanding fact remains that no major study has been made of attitudes and norms regarding sex conduct. Any conclusions must be tempered by awareness of the flimsy evidence on which they are based. Within this arena of ignorance, the American Law Institute is attempting to design new legislation concerning sexual behavior. Important recommendations are being decided at least partially on the

\footnotetext{
${ }^{10}$ See authorities cited, note 34 supra. These results refer largely to response to behavior clearly defined as deviant. Whether a given pattern of behavior is recognized as deviant in the first place is a related, but separate, issue. At least in regard to mental illness, there is some evidence that lower-class persons with little education are less likely to recognize a particular behavior pattern as that of a mentally-ill person than are more educated, middle-class persons. See August B. Hollingshead \& F. C. RedLich, Social Class and Mental Illness i7 I-93 (1958).

${ }^{50}$ STOUfFer, op. cit. supra note 34 , at 26-57.

a1 Trends consistent with those noted above have been found for one item on sex criminals taken from a national survey. In response to the question: "What do you think is the best thing to do with sex criminals, send them to a hospital or a jail?," the younger and more educated were much more likely to choose the hospital. Significantly, a majority at all educational levels favored the hospital, as did a majority in all age groups up to age 45 . See Woodward, Changing Ideas on Mental Illness and Its Treatment, 16 AM. Soc. Rev. 443 (195I).
} 
basis of guesses as to how the public or legislative officials will react. ${ }^{52}$ Consideration of controversial proposals could benefit from more adequate information on public attitudes..$^{53}$

\section{III}

\section{The Sex OfFender}

Certain types of sex offenders are either a danger to the community or a nuisance that the community need not tolerate. Their offenses include rape, indecent liberties, exhibitionism, and incest, as well as a variety of related acts. The conception that sex offenders are different from any other types of law violators has led to legislation that results in a placement of sex offenders in a kind of limbo, somewhere between the criminal and the mentally ill. The remainder of this paper directs attention to the problems raised by sex offender legislation and to some possible sociocultural factors in the genesis of sex deviation.

\section{A. History and Critique of Sex Offender Laws}

Legislation defining sex psychopaths and establishing administrative procedures for their custody, treatment, and release was passed by some thirteen states between I937 and 1950, and has been extended to other states since that time. Procedures leading up to the legislation were similar in the different jurisdictions. In a review of the development of sex psychopath laws, the late criminologist Edwin Sutherland noted a sequence characterized by (a) arousal in a community of a state of fear as a result of a few serious sex crimes, (b) agitated community response, leading to (c) the appointment of a committee that gathered information and made recommendations that generally were uncritically accepted by state legislatures. ${ }^{54}$ The work of the committees proceeded largely in the absence of facts. Sutherland noted that the laws embodied a set of implicit assumptions that were explicit in much of the popular literature on sex offenses. These included the notion that all sex offenders were potentially dangerous, that they were very likely to repeat their offenses, that they san be accurately diagnosed and efficiently treated by psychiatrists. The laws were passed in the name of science, although there was little scientific evidence as to the validity of the assumptions underlying the statutes.

\footnotetext{
"2ee the discussion of proposed changes in legislation regarding deviate scxual intercoursc. ModeI Penal Code $\$ 207.5$, comment at 276-8I (Tent. Draft No. 4, 1955).

${ }^{53}$ To be sure, there are weaknesses and pitfalls in the gathering and interpretation of opinions on controversial issues. But these problems are well known to experts in opinion-research and are subject to increasing control. One need not suggest that public opinion replace legislative and judicial opinion in order to see the value that can come from knowledge of public attitudes, especially in areas where presumed public response is explicitly considered in making important decisions. For a recent study and discussion of the use of opinion surveys and their application to one area of legal concern, see Jutius Cohen, Reginald A. H. Robson \& Alan Bates, Parental Authority: The Community and the Law (1958). This is not to suggest that public opinion studies are the only or necessarily the most appropriate means of establishing the relationship of public opinion to legal process. The University of Chicago Jury Project is one instance of a much different approach that promises to reveal some of the arcas of agrecment and disagreement between the response of judge and of jury to certain types of offenses. Sec Broeder, The University of Chicago Jury Project, 38 NEB. L. Rev. 744 (I959).

${ }^{51}$ Sutherland, The Diffusion of Sexual Psychopath Laws, 56 AM. J. Soc. ${ }_{42}$ (1950).
} 
The act of passing the statutes set in motion the kind of data-gathering process that was needed to establish adequate legislation in the first place. Some of the legislation required study of the effectiveness of the statutes along with studies of sex offenders. These studies drew attention to the weaknesses of the legislation.

Many of the criticisms have been presented in reports prepared for state legislatures and will be mentioned only briefly here..$^{55}$ The label "sex psychopath" is so vague as to make administration of statutes unreliable. ${ }^{56}$ Sex offenders are less likely to repeat their crimes than are other types of offenders. ${ }^{57}$ Very few sex offenders present a grave social danger. ${ }^{58}$ Current diagnostic techniques are incapable of distinguishing reliably between the potentially dangerous and those that are not dangerous. ${ }^{59}$ There has been no test of the assumption that treatment techniques are effective in rehabilitation of sex offenders. ${ }^{60}$

Given these findings, it is not surprising that members of the legal profession were reluctant to approve of the usual procedures for administration of the statutes. Significantly, the opposition was not along lines usually assumed to separate legal from psychiatric viewpoints: a free-will, punitive orientation versus deterministic, permissive orientation. Rather, the criticism has been directed to the possible denial of due process to offenders. Since the statutes typically called for commitment up to life, even for minor offenses, the usual safeguard of a maximum sentence was missing. In addition, the administrative procedure for release, frequently requiring certification that the offender was no longer a danger to the community, made release very difficult. Administrators were understandably reluctant to assert that the patient was cured. ${ }^{61}$

While these problems signify dissatisfaction with many of the procedures built into the earlier statutes, there is still no common agreement on the most appropriate solutions. Some states have dropped the label "sex psychopath" from their statutes, have restricted the scope of the statutes to more serious offenders, and have required that the offender be held no longer than the maximum sentence under traditional criminal provisions. One of the problems posed by these changes is

ov Reports with detailed analyses of sex offender statutes and experience in their use include PauL W. TAppan, The Habitual Sex Offender (I950) (prepared for the state of New Jersey); California Dep't of Mental Hygiene, Final Report on California Sexual Deviation Research (I954) [hereinafter cited as California Report]; Governor's Study Comm'n, Report on the Deviated Criminal. Sex OFFENDER (I95I) (Michigan).

60 Tappan, op. cit. supra note 55, at 36-42; California Report 20-38.

67 TAppan, op. cit. supra note 55, at 22-25. Tappan cites a New York study that found that only $7 \%$ of convicted sex offenders were re-arrested for sex offenses over a 12-year period. A recent California study also found $7 \%$ sex recidivism among sex offenders. See Frisbie, The Treated Sex Offender, Fed. Prob., March I958, p. r8.

${ }^{68}$ Tappan, op. cit. supra note 55, at 20-22. See also Albert Ellis \& Ralph Brancale, The PsyCHOLOGY OF Sex OfFenders 32 (1956).

${ }^{50}$ For a beginning in this direction, see California Report $\mathbf{4 2 - 4 7}$.

${ }^{00}$ TAPPAN, op. cit. stipra note 55, at $15-16$. Of course, a major problem has been that treatment has been almost totally lacking. Many states have passed laws requiring treatment without establishing treatment facilities. Beyond this, however, any treatment technique will have to be very effective if it is to reduce significantly the rate of recidivism, for the rate is already quite low.

${ }^{01}$ TAPpAN, op. cit. supra note 55 , at 34 . 
illustrated by the experience in Massachusetts. Massachusetts revised its psychopathic personality statute in 1954. The new law discarded the term "psychopath" and included the requirement that an offender must be released at the expiration of his maximum sentence. The law was deemed inadequate after a double murder was committed by an offender whose release from the state reformatory could not be prevented by provisions of the 1954 act. The law was quickly amended to allow for indefinite commitment up to life for certain types of sex offenders. ${ }^{62}$

The case points to a familiar problem in the visibility of mistakes in the processing of offenders. Errors made in releasing men too early are publicly observable. Under a statute allowing commitment up to life, however, errors made in keeping men who may, in fact, be cured cannot be tested, because by the nature of the procedure, they are not given a chance either to succeed or to fail. While every failure of early release many come to public attention, errors of keeping men too long cannot be detected. Such errors may be quite frequent in the absence of accurate diagnostic procedures. There is always the danger of undue restriction of civil liberties in attempts to provide adequate protection to the community.

\section{B. Developmental Careers of Sex Offenders}

Perhaps the single most important outgrowth of recent experience with sex statutes is that we are now aware of how little reliable knowledge is available. Until recently, the major source of ideas about sex offenders stemmed from clinical reports on a wide variety of sex deviants. The case materials have filled most of the books written on sexual deviation. ${ }^{63}$ Although the cases may enrich clinical understanding, they do not provide an adequate basis for the development of sound administrative procedures. The clinical interpretations stand logically not as fact, but as hypotheses requiring test. ${ }^{64}$ Since the cases are drawn from an unknown population of offenders, there is no adequate basis for generalization. And since adequate control groups are not employed, any claims as to therapeutic effectiveness are claims, and no more. They remain untested.

The impetus to research provided by the sex psychopath statutes has resulted in knowledge that calls into question some of the earlier clinical findings. While the research is still at a descriptive rather than an experimental stage, it has been effective in casting doubt on assertions that all or almost all sex offenders are highly dis-

\footnotetext{
ea Edwin Powers, The Basic Structure of the Administration of Criminal Justice in MassachusETrs I5-I7 (United Prison Ass'n of Mass., Res. Div. Rep. No. 5, 1957).

${ }^{a}$ Benjamin Karpman, The Sexual Offender and His Offenses (1954); Joseph Paul De River, The Sexuat Criminal (x950); Reinhardt, op. cit. supra note 48.

of For a clear, concise statement of the needs and uses of controls in psychiatric research, sec CoMM. on Research, Group for the Advancement of Psychiatry, Rep. No. 42, Some Orservations on ConTrols in Psychintric Resenrch (1959). Neglect of the distinction between fact and hypothesis is illustrated in the following exchange in a discussion of a paper on sex psychopaths written by the psychiatrist Benjamin Karpman. One of the discussants, Albert Ellis, suggested that Karpman's propositions should be regarded as hypotheses rather than facts, and that evidence for some of them was lacking; to which Karpman replied: "I deny these allegations in toto. All of my statements are based on actual clinical material; I do not have one bit of theory." KarpMas, op. cit. stspra note 63, at 511-12, 525.
} 
turbed. Systematic study of 300 offenders committed to the diagnostic facility in New Jersey showed that on the basis of psychiatric diagnoses, fully forty-three per cent of the offenders were classified as normal or only mildly neurotic. ${ }^{65}$ This raises the question of what distinguishes the psychiatrically normal from the abnormal sex offender. More broadly, are there systematic differences in the developmental careers of different types of sex offenders? Suggestions of such differences are apparent in recent research.

A distinction can be made between aggressive and passive offenders. The former usually commit offenses involving attempted or completed intercourse with a legitimate sexual object-i.e., a person of the opposite sex beyond the age of puberty. Most rapes and sexual assaults fall in this category. The passive offenses include exhibitionism and noncoital sex play with children. In terms of physical danger, the former category presents the most serious social problem. The sex statutes were passed largely to control the violent acts of rape and sexual assault. Yet, available evidence suggests that as a group, such offenders are less likely to exhibit clear-cut pathological symptoms and may have more in common with nonsexual offenders than with the passive sex deviants.

The report on sex offenders processed through the New Jersey diagnostic center provides information on the characteristics of offenders classified by type of offense. Selected findings from the study are reproduced in table four for the offense categories falling most clearly at the aggressive and passive poles. ${ }^{66}$

The aggressive offenders are more likely to be judged normal by psychiatric diagnosis. They are less inhibited sexually and tend to give fewer indications of severe emotional disturbance. Fewer of them are judged to have been exposed to severe emotional deprivation during childhood. Significantly, their prior arrest histories show few sexual offenses, but many nonsexual offenses. The ratio of nonsexual to sexual offenses is much higher for the aggressive than for the passive offenders. Finally, they are much more likely to show signs of hostility, a characteristic most common among property offenders from delinquent or criminal subcultures. ${ }^{67}$

Evidence from the California studies of sexual deviation supports the pattern noted above. Case descriptions of the most serious and aggressive sex offenses committed by delinquents in San Francisco revealed that over half of the cases were gang-

${ }^{05}$ Elzis \& Brancale, op. cit. supra note 58 , at 94 .

${ }^{\circ 0}$ See id. at $34,38,42,46,49,56,62$. Two of the major categories excluded from the above review are statutory rape and incest. Ellis and Brancale provide convincing evidence of the essential normality of statutory rape offenders, and support the conclusions of Ploscowe and others that the age limit in such cases should be reduced. Evidence on incest cases suggests, as would be expected, that offenders are more like the aggressive than the passive offenders in terms of social and criminal background.

${ }^{07}$ The findings of the New Jersey study are, of course, subject to many weaknesses commonly found in sex offender research. As the authors of the study note, there is no way of knowing how their sample differs in background from sex offenders sentenced to state prisons or from those who are undetected. The number of cases is much too small, especially for the rapists, to place much confidence in the results. The characterizations of offenders, with the exception of prior arrest data, are undoubtedly colored by knowledge of which type of offense they committed. 
TABLE IV

Differences Between Aggresstve and Passive Sex Offenders on Selected Characteristics*

\begin{tabular}{|c|c|c|c|c|}
\hline & $\begin{array}{l}\text { Diagnosed nor- } \\
\text { mal or mildly } \\
\text { neurotic }\end{array}$ & $\begin{array}{l}\text { Commitable to } \\
\text { mental institu- } \\
\text { tion }\end{array}$ & $\begin{array}{c}\text { Over- } \\
\text { inhibited }\end{array}$ & $\begin{array}{l}\text { Sovero emo- } \\
\text { tional dis- } \\
\text { turbanco }\end{array}$ \\
\hline \multirow[t]{2}{*}{ 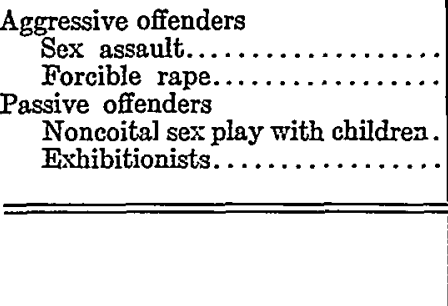 } & $\begin{array}{l}48 \\
38 \\
20 \\
30\end{array}$ & $\begin{array}{l}24 \\
25 \\
45 \\
29\end{array}$ & $\begin{array}{l}48 \\
50 \\
66 \\
72\end{array}$ & $\begin{array}{l}48 \\
63 \\
66 \\
63\end{array}$ \\
\hline & $\begin{array}{l}\text { Previous arrest } \\
\text { for sex offenses }\end{array}$ & $\begin{array}{l}\text { Previous non- } \\
\text { sex arrests }\end{array}$ & $\begin{array}{l}\text { Underlying } \\
\text { hostility }\end{array}$ & $\begin{array}{c}\text { (No. of } \\
\text { subjeots) }\end{array}$ \\
\hline $\begin{array}{l}\text { Aggressive offenders } \\
\text { Sex assault. } \ldots \ldots \ldots \ldots \ldots \ldots \ldots \\
\text { Forcible rape. } \ldots \ldots \ldots \ldots \ldots \ldots \\
\text { Passive offenders } \\
\text { Noncoital sex play with children. } \\
\text { Exhibitionists............. }\end{array}$ & $\begin{array}{l}14 \\
12 \\
\\
51 \\
34\end{array}$ & $\begin{array}{l}48 \\
50 \\
\\
43 \\
23\end{array}$ & $\begin{array}{l}72 \\
75 \\
\\
35 \\
25\end{array}$ & $\begin{array}{l}21 \\
8 \\
51 \\
89\end{array}$ \\
\hline
\end{tabular}

* Each column contains the percentages of each type of offender characterized as indieated by column headinga. Thus $30 \%$ of the exhibitionists were diagnosed normal or only mildly neurotic. Number of cases on which tho percentages are based appear in tho lower right column.

motivated. Furthermore, of the thirty-seven serious offenders studied, half had previous records for nonsexual offenses, only three had previous sex arrests. Reading of the case descriptions further shows that the gang attacks were most frequently directed toward girls in middle or late adolescence, while the offenses against very young sexual objects were more likely to be committed by lone offenders. ${ }^{68}$

Ethnic differences in rates of sex offenses give further support to this pattern. The California research showed that Negroes and Mexicans were overrepresented in the rape category, underrepresented in offenses against children. ${ }^{00}$ The New Jersey experience suggested that Negro sex offenders were less emotionally disturbed than their white counterparts. ${ }^{70}$ Both of these findings are consistent with studies of racial differences in homicide rates and suggest the influence of cultural differences in restraints on the use of violence to resolve interpersonal affairs. ${ }^{71}$

The evidence thus suggests that the typical aggressive sex offender may be less "sick" than is usually supposed. Their backgrounds have much in common with nonsexual offenders who come from crime-inducing cultural settings. Instead of conceiving of their conduct as resulting from a highly specific and grossly deviant sexual motivation, it is perhaps more valid to view their offenses as part of a broader behavior system in which force may be used to attain their goals. It is the use of force, rather than any specifically deviant sexual motivation, that distinguishes these

\footnotetext{
${ }^{\circ 8}$ CALIFORNIA REPORT 132-35.

${ }^{60}$ Id. at IOI-02.

${ }^{70}$ Ellis, Doorbar \& Johnston, Characteristics of Convicted Sex Offenders, 40 J. Soc. Psych. 14 (1954).

${ }^{71}$ Marvin E. Wolfgang, Patterns in Criminal Homicide 329 (1958).
} 
offenders from those who fall within the law. ${ }^{72}$ Psychiatric study has revealed the frequency with which sexual motivations underlie such nonsexual crimes as arson and certain types of burglary. The suggestion here is that the reverse may hold for certain types of aggressive sex offenders. In a society stressing active mastery of the environment over passive acquiescence, perhaps it is not surprising that the aggressive sex offender who overresponds is judged less disturbed than the passive exhibitionist. ${ }^{73}$

Brief mention may be made of two additional points where sociological conceptions usually applied to nonsexual offenses may have bearing on deviant modes of sexual response. One of these points concerns the way in which the social structure exerts pressure on persons to use deviant means of achieving culturally acceptable goals. High rates of deviance are presumed to occur among those segments of the population that are least fortunately situated in terms of their abilities to achieve valued goals by legitimate means. ${ }^{74}$ The same conception is applicable to the achievement of sexual gratification. Prisons are, of course, an extreme case of a structure that promotes deviant means of sexual outlet. But less extreme instances are in evidence as well. Thus, two studies note high rates of incest in rural populations, where the choice of alternatives to the wife, given dissatisfaction with her performance, is severely limited. ${ }^{75}$ And prostitution flourishes in lumber and mining areas and in the central sectors of cities, where the sex ratio is abnormally high. These illustrations remind us that the availability of legitimate sexual outlets is itself socially-structured; resort to deviant outlets will reflect these structural features and need not be conceived solely as a result of faulty personality makeup.

Second, the dyadic character of many types of crime means that the victim may play more than a passive role. Wolfgang's recent study of Philadelphia homicides revealed that fully twenty-six per cent were victim-precipitated.76 Similar findings

${ }^{72}$ The psychiatrist Richard L. Jenkins has observed that "the difference between the law-abiding man and the rapist lies typically not in a difference of sex impulse, but in a difference of inhibition and consideration for the personality of others." Jenkins, The Making of a Sex Offender, in CLYDE B. VEDDER, Samuel Koenig \& Robert E. Clark, Criminologx 293, 295 (I953). The above observations seem consistent with this view, but are at variance with psychiatric analyses, which see even statutory rape as fundamentally tied up with the oedipus complex, representing an unconscious attack upon the parent. See, e.g., David Arrahamsen, Who Are the Guilty? 184-85 (1952). Any theory that seeks to interpret sex aggression as a highly neurotic or psychopathic act must consider the prevalence of aggressive sexual acts among presumably normal populations of college students. See Kanin, Male Aggression in Dating-Courtship Relations, 63 Ax. J. Soc. 197 (1957). The Kanin article points to some of the factors that may prevent these cases from becoming officially labeled as felonious aggressions.

${ }^{73}$ The culture of prison inmates provides insight into the differences between aggressive and passive sex offenders. No special status is conferred on aggressive offenders or those convicted of statutory rape. In fact, the latter are viewed as having "bum beefs" as a result of "pick on your own size" laws designed to allow promiscuous teen-agers to get off the hook when they become pregnant. Offenders who engage in nonviolent sex acts with children, on the other hand, are relegated to the bottom of the social structure and referred to in derogatory terms as "rapos"-so afraid of women they had to pick on children.

T' Sce Robert K. Merton, Soctal Theory and Social Structure 13I-94 (rev. ed. 1957).

${ }^{75}$ John Lewis Gillen, The Wisconsin Prisoner I07-r6 (1946); Reimer, The Background of Incestwous Relationship, in VEDDER, KoENIG \& CLARK, op. cit. supra note 72, at $30 \mathrm{x}$.

${ }^{70}$ Wolfgang, op. cit. stupra note $7 x$, at 245 . 
might result from careful study of those convicted of rape, where the offense frequently follows an evening of drinking and mutual sexual arousal. Consideration of the victim's role means that the offense can be viewed as a product of a social situation; its explanation cannot easily be reduced to a search for the childhood emotional disorders of the party who becomes labeled the offender. ${ }^{77}$

These observations suggest some ways in which sociocultural and situational features may be related to deviant sexual behavior. Assumptions that direct attention solely to psychogenic factors may lead to an inaccurate conception of the causal processes involved, and hence to treatment programs that neglect important sources of the deviation. Specifically, further research may reveal that many aggressive sex offenders are responding to culturally learned patterns of aggression and to situational factors that are unlikely to be relieved by the usual methods of clinical psychotherapy. Patterns of cultural learning as well as psychogenic disorders may be reflected in their offenses. This may partially explain why such offenders are deemed generally less amenable to treatment than the less dangerous but more disturbed passive offenders. ${ }^{78}$

Sociological conceptions of crime are heavily influenced by the sociologist's concern for the impact of culture and social organization. These elements are revealed most clearly in such types of offenses as professional crime, white-collar crime, and gang delinquency. Some of the evidence reviewed above suggests that there may be important sociogenic features in the development of certain types of sex offenders, and that further study could profit from an interdisciplinary approach to the problems posed by such offenders. The growing need for systematic knowledge should lead to research designed to reveal the combined influence of sociogenic and psychogenic sources of sexual deviation. Such research may suggest inadequacies in the conception that most sex offenders are a special breed of criminal requiring unique laws and administrative procedures for their control.

77 The Model Penal Code expresses recognition of these elements in suggesting that where a woman loses capacity to control her own conduct by voluntary use of intoxicants or drugs, any resulting intercourse cannot be charged as rape, although it can be under most existing statutes. Mopec Penat Code $\S 207.4$, comment at $248-49$ (Tent. Draft No. 4 , 1955).

${ }^{78}$ Ellis \& Brancale, op. cit. supra note 58 at 78 . 